\title{
Religious Pluralism and Interfaith Coexistence: Ecumenicalism in the Context of Traditional Modes of Tolerance ${ }^{1}$
}

\author{
David Owusu-Ansah \\ Professor of History \& Associate Provost for Diversity \\ James Madison University, United States of America \\ E-mail: owusuadx@jmu.edu \\ Emmanuel Akyeampong \\ Gurney Professor of History and \\ African and African American Studies \\ Oppenheimer Faculty Director \\ Harvard University, United States of America \\ Email: akyeamp@fas.harvard.edu
}

Submitted: January 3, 2019/ Accepted: September 9, 2019/ Published: December 30, 2019

\begin{abstract}
In many parts of the non-western world, religion is singled out as the cause for violent clashes. At the 2007 TrustAfrica workshop in Dakar, the conference of religious leaders, scholars, and experts from 12 African countries and the Diaspora explored this concern under the theme "Meeting the Challenges of Religion and Pluralism in Africa." It was observed that religiously justified conflicts were often the repackaging of community concerns regarding issues of social, economic, and political injustices, inequities and exclusions. Consequently, a project on "religious pluralism and interfaith coexistence in Ghana" was funded in 2008 as part of the efforts to examine the role of local traditions as a foundation to interfaith dialogue. Earlier in 2005, a similar project on the theme of Islam and tolerance, with funding from Harvard and Michigan State University, was conducted in Ghana. ${ }^{2}$ Several issues emerging from the field conversations are pertinent to topics of how history shaped Muslim relations with their non-Muslim hosts in West Africa. It is often argued in the literature that Islam's inherently adoptive attitude toward African religious culture made it possible for Muslims and their non-Muslim hosts to co-exist. However, this research contends that, in the case of Ghana, it was the traditional local culture as defined by indigenous religious values that shaped and moderated the environment that sustained peaceful interreligious relations. The authors express concern that as the country experiences rapid urbanization, Westernization, proliferation of charismatic churches and aggressive Christian evangelization, the traditional values that underpinned pluralism and peace in historic times might be threatened (George Bob-Milliar and Karen Lauterback, 2018).
\end{abstract}

Keywords: Traditional cosmology, spiritual knowledge, power, ecumenism, the common good, religious tolerance, pluralism, syncretism, peaceful national coexistence

\footnotetext{
${ }^{1}$ David Owusu-Ansah presented a version of this paper at the 12 Annual-Lecture in Honor of Professor Nehemia Levtzion held at the Levtzion Center for Islamic Studies, Hebrew University, Jerusalem, on 20 March 2017.

${ }^{2}$ Interviews used as source material for this paper came from our fieldwork in Ghana in 2005 through 2008. Rebecca Tandoh and our colleague the late Dr. Mark Sey were members of the research team.
} 


\section{Introduction and Review of Literature}

In the age of Al-Qaeda in the Maghreb, Boko Haram and al-Shabaab terror operations on the continent of Africa, it is important that the literature on religious co-existence and the peaceful Muslim and non-Muslim interactions in the history of West Africa be revisited. In his book titled Muslims and Chiefs in West Africa (1968), Nehemia Levtzion focused not so much on the spread of Muslim traders in the region, but rather on the activities of Muslim clerics whose ventures into the non-Islamic territories of the Volta Basin started the process of Islamization of the area and beyond.

Composed of the Dagomba, Gonja, Gurma, and Nanumba now in territories of modern Ghana, and the Mossi, Gurma and Grunshi in modern Burkina Faso, Levtzion, similar to scholars such as Lamin Sanneh (1976) and Ivor Wilks (2002), examined the history of clerical services that Muslims performed for non-Muslim rulers. Over time, local lords such as those in Dagomba and Gonja came to "accept" Islam but the majority of their rural communities remained traditionalists.

From the writings on the Islamization of North Africa and Egypt to the scholarship that examined the role of Muslim clerics in traveling trading caravans across the Sahara, and to the works on conversion and the Islamization of subSaharan West Africa, urban centers were presented as characterizing the seats of traditional rulers and therefore of commerce. Such locations favored traders and clerics who spread the influence of Islam. The rural regions where the majority of the non-Muslim locals resided were places where puritan Muslims retreated when they became dissatisfied with the quality of urban Islam, and in some cases, these were sites from where jihads were planned and staged. This bifurcation is evident in the volume co-edited by Levtzion and Humphrey Fisher under the title of Rural and Urban Islam in West Africa (1987). While it is important not to portray traditional society as unchanging, it is important to note that African villages remained predominantly traditional and retained the purity of the local cosmology to which were attributed all the spiritual agencies that determined the factors of production. ${ }^{3}$ There was indeed the belief that the effective combination of hard work, fertility of land and even the availability of capital and labor were not sufficient guarantors of productive outcomes.

In the Akan forest environment, which includes territories in modern Ghana and parts of the Cote d'Ivoire, balance was sought between the sacred and profane

\footnotetext{
${ }^{3}$ An important observation needs to be made here that we are not portraying traditional society as unchanging. We have seen works that have examined how the bori cult in Nigeria, for example, responded to social change, including Islam and colonial rule. See for example, Adeline Masquelier, "Narratives of power, images of wealth: the ritual economy of Bori in the market," in Modernity and its Malcontents: ritual and power in postcolonial Africa, edited by Jean Comaroff and John Comaroff, University of Chicago press, 1993.
} 
existence and the knowledge of those who were able to tap into spiritual power was of great importance for the collective good of the community. It was crucial to maintain relations with the spirit-world because of the various benefits inherent in such association. The forest shaped Akan cosmology and conceptions of power, as Thomas McCaskie has insightfully demonstrated in several important works (McCaskie, 1983 and 1992; Akyeampong and Obeng, 1995). While much emphasis in the literature had focused on the impact of urban Muslims in converting West African communities, it is the position of this paper that it was rather the strength of the rural and indigenous cosmology that often-shaped inter-religious relations (Akyeampong and Owusu-Ansah, 2014; Owusu-Ansah, 1991) - for the color of water is really a reflection of the soil over which it flows.

Scholars such as Peel and Horton (Horton, 1971; Horton and Peel, 1976) saw this African rural character to be something with which Islam was familiar. Cosmologically, the presence in Islam of a powerful God whose blessings could be tapped through the services of clerics was attractive and one of the compelling reasons for the conversion of local rulers. However, as Levtzion often demonstrated in his writings, conversion was often a rational decision and therefore the Muslim presence in West Africa, even when it led to conversion, did not necessarily lead to the abandonment of the indigenous practices. Ivor Wilks on his part attributed the legacy of tolerance and accommodation - the gradual Islamization and the retention of vestiges of indigenous practices that were characteristic of Islam in the Volta Basin - to the teachings of al-Hajj Salim Suware (Wilks, 2002). The $15^{\text {th }}$ century Mande scholar advocated that true conversion occurred in God's own time and not by the force of the sword - an accommodative situation that often led to the mixing of Islamic practices with the indigenous religious culture (Bravmann, 1983).

Syncretism, if embraced in a pluralist culture, will presuppose that citizens, who are committed to different and not necessarily agreeable religious doctrines, will arrive at an accommodation for their common good. However, as Charles Stewart observed in his essay titled "Syncretism and its synonyms" (Steward, 1999), the term has a history of being used in pejorative ways to connote the absence of purity, or to describe the concept of cultural mixing and hybridization. Thus, for Islamic purists such as Askia Muhammad of Songhay, or Uthman dan Fodio of Hausaland, syncretism was a condition that was unacceptable and needed correction via jihad - a process that Claude Meillassaoux observed to have been linked also to razzia or slave raiding in the Western Sudan (Meillassoux, 1993). Given the history of jihad as the effective mode of Islamization, it is difficult to accept the argument that the teachings of Salim Suware were the only sources by which cases of peaceful 
propagation of Islam in West Africa might be attributed (Hanretta, 2005). ${ }^{4}$ In other words, research on peaceful religious coexistence should not always be assessed on the ability of the hegemonic religious cultures of Islam and Christianity to make accommodative adjustments. Indeed, it is prudent to ask whether there were values within the indigenous religious environment that also embraced pluralism and contributed to peaceful coexistence.

\section{The Color of Water: Contextualizing Ghana's Cultural}

\section{Tradition of Religious Tolerance}

In two ethnographic projects (2005 and 2008) that Owusu-Ansah and Akyeampong were a part of, the research explored the values of ecumenism in the context of the Ghanaian traditional culture. The first project, "Diversity and Tolerance in the Islam of West Africa," was a United States Department of Education funded research for Harvard and Michigan State University in 2005. The second was the TrustAfrica-sponsored research that focused on interviewing leaders and attendants of indigenous shrines. By this second project, the topics for the 2005 research conversations were expanded to cover issues on tolerance and religious pluralism in Ghana. The conversation topics covered a larger spectrum of beliefs. Muslims, Christians, and Indigenous Practitioners have a record of peacefully coexisting in the country. From these field inquiries, it was concluded that, indeed, in the case of Ghana, it was rather the indigenous cosmology that laid the foundation for religious ecumenism. The earliest Muslim travelers like Ibn Battuta from North Africa or the "central lands of Islam" to visit Muslim societies in West and East Africa, whose very travels had been facilitated by the Muslim leaders and traders in these societies, were critical of practices they considered unIslamic (Bovill, 1995). Christian missionaries in $19^{\text {th }}$ and early $20^{\text {th }}$ century Gold Coast (e.g., Basel missionaries), wedded to the belief in Acts 4:12 that there is no other name on earth that can save but the name of Jesus, encouraged early Gold Coast converts to physically move away from their villages and towns to reside in Christian Salems or residential quarters, where they could practice their new faith in purity. Clearly, the inspiration for religious pluralism in the Gold Coast or Ghana did not originate in these two universal faiths.

In comments on religious pluralism in Senegal, the country's former leader President Leopold Senghor was purported to have estimated that Senegalese were

\footnotetext{
${ }^{4}$ In a wonderful review of the Nehemia Levtzion and Randel Pouwels' edited book, The History of Islam in Africa, Ohio (2000), Sean Hanretta cautioned scholars to be mindful of attributing all cases of peaceful co-existence and the absence of jihad to the influence of Suwarian traditions. Hanretta called on researchers to avoid the "pitfall in the literature whereby every failure to wage jihad is explained by references to the influence of Suwari, whether that influence is really attested or not."

${ }_{5}^{5}$ For detailed information about the project and related interviews in the context of "Diversity and Tolerance in the Islam of West Africa," go to Michigan State University Digital Online Library: www.aodl.org.
} 
Owusu-Ansah, D. \& Akyeampong, E/Religious Pluralism and Interfaith Coexistence: Ecumenicalism in the Context of Traditional Modes of Tolerance 90\% Muslims, 10\% Christians, and 100\% animists. ${ }^{6}$ A 2010 research at the Pew Foundation Forum on Islam and Christianity in Sub-Saharan Africa, lent credence to the Senghor claim of local cultural contents. In fact, the research observed that when respondents in Sub-Saharan Africa were asked to describe their religious beliefs and practices, a paradox emerged. "The survey findings suggest that many Africans are deeply committed to Islam or Christianity and yet continued to practice elements of traditional African religions" (Pew Research Center, 2010). It is from such observations that the strict interpretation of census information represented in graphs, even in the Pew research, could be misleading at first glance. ${ }^{7}$ Growth of Islam \& Christianity in Sub-Saharan Africa Since 1900

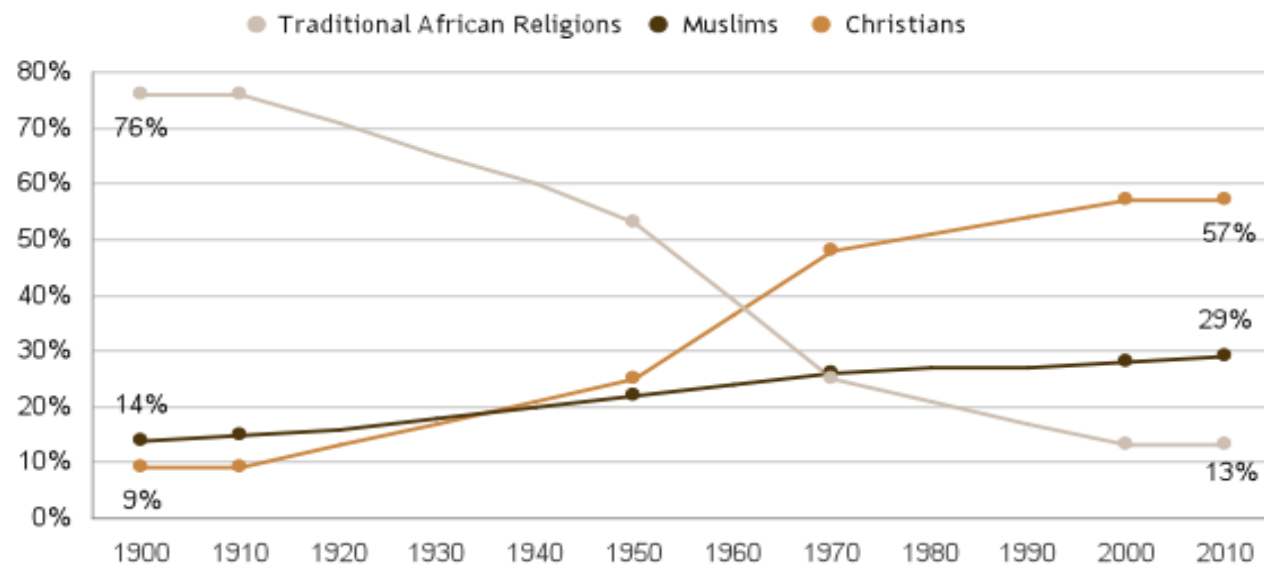

Source: World Religion Database. Historical data draw on government records, historical atlases and reports of religious organizations at the time. Later figures draw on U.N. population estimates, surveys and censuses.

\section{Pew Forum on Religion \& Public Life, April 2010}

In the last national census of Ghana in 2010, Christians from all denominations were recorded at the $60^{\text {th }}$ percentile, 16 percent Muslims, and the remaining Indigenous and "others". A more recent estimate divides the country's population into about 70 percent Christians, almost 18 percent Muslims and the rest as Indigenous and others (Ghana Statistical Service, 2011; See also, worldpopulationreview.com/ countries/ghana-population). Yet, the local soil in which Islam and Christianity were sown contribute enormously to the accommodative interfaith relations in

${ }^{6}$ For a more detailed conversation on Christian-Muslim relations in Senegal and the thoughts of President Senghor therein, see Souleymane Bachir Diagne, "Religion and the Public Space in Senegal: The Evolution of a Project of Modernity," presented at the Institute for the Study of Islamic Thought in Africa (ISITA), Working Paper Series, Northwestern University, March 2009

${ }^{7}$ Website for the Pew Forum graph is at: https://www.pewforum.org/2010/04/15/executive-summary-islam-and-christianity-in-sub-saharan-africa/. 
this country where traditional leadership (the stool in the south, the skin in the north) continues to be understood as an embodiment of religious and political power. Power is perceived as multi-sited, as distinct from authority that was politically sanctioned. Traditional leaders explored and engaged multiple sources of religious power and sought to harness these for the interest of polity and chief (Akyeampong and Owusu-Ansah, 2014). Therein lies the rationale for the evolution of an institution like the office of the Nsumankwaa or traditional royal physicians in the Akan chiefdom. The continuing saliency of chieftaincy in colonial and independent Ghana has ensured the survival of indigenous religions and traditional values, including that of religious coexistence (Amponsah, 2018). In addition, as the first head of state of an independent Ghana, Kwame Nkrumah, sought to create a Ghanaian nation-state, where the three major religious traditions were incorporated to make familiar and acceptable at state functions the performance of prayer through libation, by a Muslim Imam, and by a Christian minister. Based on the preponderance of evidence, we concluded our research with the hypothesis that the greater the level of syncretic pluralism, the higher the possibility of religious tolerance. We present here three separate ethnographic accounts from the field as examples of indigenous ecumenism that continues to define religious tolerance in the modern state of Ghana.

\section{Field Interviews and Observations}

\section{Summary of Interviews with Archbishop Dr. Peter Kwasi Sarpong ${ }^{8}$}

In several publications spanning almost six decades, Catholic Archbishop of Kumasi Dr. Peter Kwasi Sarpong observed that the African traditional religious environment contributes greatly to peaceful ecumenical relations that allow for religious unity (Sarpong, 1974, Osei-Bonsu, n.d.). While he admitted that the Ghanaian environment has not been free of conflict, he attributed the occasional clashes to those he referred to as "small fundamentalist groups who insist on the exact interpretation of the words of either the Bible or the Quran." He further observed that "indigenous religion has not been a source of religious conflict in Ghana because it does not have a 'Book' that says categorically this or that." Rather, he pointed to traditional cultural practices, which are always imbued with religious value. In addition, shared family and community activities such as the performance of rite of passages have public spaces and built-in ecumenism and therefore venues for peaceful interactions. Such performances do link to spiritual agents that are believed to contribute to the common good.

\footnotetext{
${ }^{8}$ Emmanuel Akyeampong conducted these interviews with Archbishop Peter Akwasi Sarpong (dd. 15 June 2005, Santaase, Kumasi). For the full interview, see aodl.org/islamictolerance/asantehistory//object/3C-18C-10/.
} 
In other words, religiosity was defined not in terms of affiliation to any specific Christian denomination, Islamic sect, or any particular local shrine. Rather, religiosity was presented as relating to the sense of believing in and associating with spiritual agents that are understood to be capable of contributing to a peaceful and prosperous existence. Religion therefore serves the practical needs of a people and therefore it is not surprising to find members of the traditional extended family who share the common compound but still affiliate to different religious faiths. The Archbishop illustrated this with a story of his own childhood experiences where his family kept a shrine but also switched from one religious' faith to another including association with Muslims:

Personally, I am an Asante... and my father's village is adjacent to my mother's village. If you go to my village and somebody did not tell you that this building is in Maase [village in the Offinso District] and the next one is Mpenne, you will not know where the boundary begins... Interestingly, in my mother's house we had Muslims who lived there and in my father's, [also] there were Muslims. Every day, at my father's house, the Muslims were teaching the Muslim children the Quran, and suddenly I was even reciting the Quran [as a child]. So, there was such a good [relationship] and that was my experience. Even now when the chief Imam celebrates the Ramadan [fast] and they kill a cow or a sheep, they present me with some and whenever I go on pastoral visits to villages, I have the great satisfaction when Muslims come to meet me, not just to greet me, but they attend my mass and after mass they will come to receive the blessing from me...

You talked or mentioned the Nsumankwaahene: Whether at a formal occasion or informal occasion, when the Nsumankwaahene sees me, whether he is engaged in formal activities or not, this man will bow to me [in recognition]. He calls me "Nyame Komfo" [the fetish priest of the Christian God]. Many of the things I say in my books are not taken from [other peoples'] books. I am a typical village boy... I [started] schooling by accident and I lived the life of nature and the true African boy at a village about three miles from Maase. [In addition], in my household, I had five fathers, which means that my biological father had four brothers [and I call all of them father]... The interesting thing in the setup of my household was that my father's eldest brother (Kwadwo Gyinaye) was a [traditional] fetish priest, then the other brother (Kwaku Agyin) was a Catholic, then came my father (Kwabena Marfo, popularly known as Kwabena Donkor...) who was born during the Yaa Asantewaa War in 1900 became a Catholic three months following my birth. His younger brother (Amo) was a Catholic and the last brother (Kwaku Badu) was not anything or could have been anything. Later on, the first brother Kwadwo Gyinaye the traditionalist became a Catholic, and Amo, the good catholic, became 
a traditional priest. And I can tell you that he became a zealot Catholic who used to call himself "Adikan abedi akyire" [the first who has become the last] and he called himself "Paul". So, as I was saying, many of the things I have written about in my books (if I am not exaggerating) they have come from the experiences of my childhood. So, here I was in the middle of religious tolerance (Akyeampong, aodl. org/islamictolerance/asantehistory//object/3C-18C-10/).

What Archbishop Sarpong talked about as domestic ecumenism and pluralism in Ghanaian traditional society does not mean a lack of a definite knowledge of a monotheistic God. His central thesis was the argument that the European missionaries, who propagated the gospel, did not appreciate the culture within which they worked. He therefore called on the Church in its modern setting to develop an African theology by which Christian values would be explained appropriately to the people. Had that been done, he argued, the common religious values inherent in the local culture would have been tapped to strengthen the Christian message in Africa.

\section{A Day at the Antoa Anyaman River: Injunctions, Adjudication, and Reconciliation: Field Observations from Antoa Shrine ${ }^{9}$}

A shrine is the most traditional religious object and site in Ghana. In the precolonial era, every important household in the village setting had a shrine similar to that commented upon in the narrative by Archbishop Sarpong. Additionally, and across the country, there were popular and powerful shrines that people from all walks of life visited for spiritual consultation - for divination and to seek amulets and charms defensively for protection and offensively to attack enemies. Since the shrines counseled living together in harmony, it was imperative that the traditional communities adhered to the moral codes of conduct associated with any given shrine with which they were attached. The day spent at the Antoa Anyaman River Shrine provided the best example of how deities adjudicated conflicts and intolerance.

From the research and visit to Antoa, a village not far from Kumasi, we came to know that the shrine has an attending priest but the river "belongs" to the local chief and therefore the elders of the village's royal family serve as custodians and on the village council to the shrine. Thus, all cases brought before the shrine are first introduced to these elders, who adjudicate cases in the name of chief and deity. The elders discuss the cases that are brought before them, ask a lot of questions of the consulting clients, provide advice and punishment, and recommend fines, but it is the priest of the shrine who performs all the rites associated with ritual cleansing.

\footnotetext{
${ }^{9}$ Field observations by David Owusu-Ansah and Emmanuel Akyeampong (dd. 12 July 2008). For the full interview and observations from Antoa, see 2008 Interview with Antoahene Nana Kwame Owusu-Agyeman I at aodl.org/islamictolerance/asantehistory//object/3C-18C-17/.
} 
The process of arbitrating conflict at the shrine is similar to those that are conducted at any traditional home or village in Ghana. Household or village elders constitute as council to address disagreement, adjudge wrongdoers and assign fines, but alternatively, a party that feels aggrieved may invoke the name of a deity to declare absolute innocence. Such an act, as understood in Akan culture, immediately brings the deity into the adjudication process (Hagan, 1968). ${ }^{10}$ The consequence of guilt is costly and in the olden days might have even resulted in the punishment of death. This was the case because the invocation of the deities in the declaration of injunction was always predicated on the challenge that the full force of the deity must be used to punish those who make unfounded accusation or false declarations of innocence. The deities are moral arbiters - they detest lies, cheating, dishonesty, and hold the position that there could be no reconciliation and forgiveness without truth telling and the full admission of guilt by offending parties. Thus, it is believed that, where the name of a deity is invoked in a conflict, ultimately the guilty party will be inflicted with sickness or misfortune as sign of guilt. This can only be removed with a visit to the deity where the appropriate rituals are performed following the peaceful adjudication of the original conflict to the satisfaction of all parties.

During the day of our visit, we noted that visitors to the shrine included persons from all religious backgrounds. The cases brought before the elders of the shrine for adjudication were very similar to those that would have been brought before a court of law. These included cases about marital issues and disagreements, ordinary theft, land litigations regarding disputes over ownership and boundaries, conflicts over rent payments between renters and property owners, unfounded accusations for which the accused was seeking redress and damages, and even efforts to redress unfulfilled promises that lovers made in the state of passion.

What was impressive was the rapidity with which people agreed to tell the truth. The guilty parties, prior to being taken to the riverside for cleansing, were individually paraded through the streets of the village in public disgrace. This whole process provided opportunity for moral education and conflict reconciliation. Thus, even though many Ghanaians identified themselves as Christians in the national census, their fears and modes of resolving conflict could very well be determined by their traditional cultural values and anxieties. The public perception of the tendency of indigenous deities to mete out instant justice encourages confession by even the uninitiated when guilty to avert the wrath of the deity. These values in the culture do reflect a history of tolerance that is based on the idea that a sinful society is a community at risk of self-destruction.

${ }^{10}$ The ultimate act of calling on the sacred (ntam bo) in the declaration of one's innocence in Akan society is the swearing on the Asante sacred Golden Stool. 


\section{Conversation with Baffour Amisare II, Chief and Custodian of Tano Shrine at Tano Oboase ${ }^{11}$}

"Abosom" or deities are attached to every important stool in Akan societies; this point was repeatedly affirmed in our conversations with traditional elders regarding the role of shrines in the history of Ghanaian culture. Among the Akan of Ghana, the stool symbolizes political authority because it is believed to encase the ancestral spirits of previous rulers (Sarpong, 1971; Quarcoo, 1990). It provides legitimacy to political rule. Thus, the history of deities and their importance to society are intrinsically linked to that of prominent traditional families or settlements. Both deity and the traditional state prefer tranquility. The role of deities as protectors of the traditional state and as agencies for the assurance of stability and peace are therefore a part of the national history on tolerance.

The narratives about relationships between deities and states are preserved in the context of various local oral traditions. Examples of such accounts relate to migration stories, the discovery of better settlement sites, as explanations of religious and/or political changes in the affairs of the community, in interpretations for the outcomes of past military encounters in the earlier state formation period, and/or as explanations in customary precedence. ${ }^{12}$ Of the several interviews conducted at traditional palaces and shrines across the country, the conversation with significance on the subject of religious ecumenicism was held on 15 July 2008 with Tano Oboase chief Nana Baffour Amisare II. Present at this palace interview were the following traditional officials: Nana Adomako Akyeampong (Nifahene), ${ }^{13}$ Tano Komfo Oppong Kyekyeku (traditional priest), Okyeame Nana Yaw Boadi (Linguist), and Tano Oboase Tour Guide Mr. Osei Tano Brempong.

It is essential to report that during this period of interviews, Dr. Emmanuel Akyeampong and our late colleague Dr. Yaw Bredwa-Mensah were also engaged in research at Bono Manso, a site known for its links to the powerful Bono state. Later in the week, we joined Dr. Bredwa-Mensah to visit the historic village of Tano Oboase and toured the ruins of the historic Tano site from where several Akan groups trace their ancestral migrations.

In the conversation with Nana Amisare II and his elders, we learned about how Tano Oboase became part of the Asante nation, how the royal house of Tano

\footnotetext{
${ }^{11}$ Interview by David Owusu-Ansah (dd. 15 July 2008). To access the full interview with Tano Oboasehene Nana Baffour Amisare II and his elders, go to aodl.org/islamictolerance/asantehistory//object/3C-18C-18/.

${ }^{12}$ Several such interviews were recorded in both the 2005 and 2008 field interviews referred to earlier in the essay. Specifically, see Emmanuel Akyeampong and Rebecca Tandoh (dd. 23 April 2006), Interview with Opanyin Kwabena Buor, Head of the Boahen Amantuo family. The narrative told the story of the role of the Mampong deity, Mpra, in facilitating an historic migration and in determining the selection of the site for settlement. Subsequently, Mpra contributed to establishing Mampong as a prominent Asante state. See, kora.matrix.msu.edu/files/60/396/3C-18C-F-106-14_Opanin Kwabena Buor Mampong.pdf.

${ }^{13} \mathrm{Nifa}$ is the Akan word for "right" as distinct from benkum or left. The Nifahene in the traditional Akan chieftaincy structure was the right wing/flank command of militia that protected the king when Akan states or Oman went to war. In his Asante in the nineteenth century, historian Ivor Wilks referred to these ahenfo or chiefs as captains who participate in the critical decision making processes of the Akan state.
} 
Oboase became responsible for attending to the shrine. We also learned that the river-deity is called "Taakora" 14 for the fact that the spirit of the river does not condone evil and untruthfulness. In a chronological fashion, it was stated that it was rather the spirit of the river-deity that possessed one Afua Akoma, who was the ancestral grandmother of the Tano royal family, indicating how nature-deities predated the founding of settlements. Since she could not effectively attend to the deity during her menstrual cycle, she transferred those priestly duties to her male counterpart, the chief. Thus, technically, the Tano Oboase chief is a traditional priest who "lifts the shrine" when he is in the company of the King of Asante (Asantehene). On any other occasion, a fulltime Tano priest (bosomfo) performs the day-to-day responsibilities of attending to the shrine.

In addition to describing his duties as chief and attendant of the shrine, Nana Amissare II also identified himself as a Christian and a member of the local Catholic Church. However, he did not see his roles as chief and custodian of the shrine to be in conflict with his membership of the Catholic Church and his faith as a Christian. Asked, if on the other hand the Church has any concern that, a member of its congregation is not only a traditional chief but also an officiant of an indigenous shrine, Chief Baffour Amisare II responded as follows:

Look, I go to Church and I pay my membership dues. The Church says "thou shall have no god besides the Lord" and we know that the deities believe in God and we believe in this one God (authors' emphasis). I have chosen on my own accord, however, not to attend the communion but in my heart, I do not see any conflict or disagreement between serving the shrine and worshiping God at the Church because the deity derives its power from the same God. So, I am not concerned about what humans will tell me regarding a possible conflict between these two ways of serving God. I go to Church and nobody chases me out from worshiping there. Moreover, on the occasions when I perform our duties regarding the shrine, they (the people from the community) come to join us. Besides, no Pastor of the Church has ever assumed the leadership of the Church in this community without coming first to greet me before he takes his post (Owusu-Ansah, Field interviews, 2008).

Even though the chief admitted that such clerical visits could be viewed as only a courteous protocol extended to him as head of the village community than an acceptance of his primary role as custodian of the shrine, the chief also rationalized that were there not a Tano River Shrine at the settlement, there would not have been any village for a Church to be established and therefore a priest to be assigned. Indirectly, therefore, those clerical visits were also in recognition of the river (water) that made community life possible, and the shrine that reflected the relationship between the river deity and the community.

14 "Taakora" is composed of the words, "Tano" (the name of the River) and "akora or akokora" (the Old man or that which is ancient). It is an important attribute that elderly persons adhere to truth for the good of the society. 
These arguments are less about any specific debate about who recognizes whom. Rather, they relate to religious tolerance - a subject that is often treated and defined by scholars of religious conversion in such terms as syncretism and eclecticism. The most appropriate topic of discussion in this case of religious encounters is embedded in the phraseology of the "weight of tradition" - a subject that Akyeampong evaluated in the portrait of Asantehene Agyemang Prempeh I, c. 1888-1931, as a Christian and a modern man, but also as a traditional ruler. Akyeampong's essay recounts the story of an Asante king, who is transformed into a "modern" man while in British exile on the Island of Seychelles. The king learned to read and write the English language; he accepted the teachings of the Anglican Christian denomination; and yet, he held on to his traditional responsibilities as king (both in exile and upon his return). He attended to the traditional stools of the ancestors; abided by the sanctions of the most sacred object of the state - the Golden Stool; he practiced polygamous marriage upon his return from exile and was unwilling to abolish the royal harem, and yet remained Christian. Akyeampong's portrait of this modern Christian king is about a person who did not abandon traditional ideas, principles, or ideals totally. To ask whether this king was indeed a Christian would be equal to questioning whether the more than 60 percent of the Ghanaian population that responded in the 2010 census to be Christians had ceased belief in and practices of elements of traditional religion. What is clear, however, is the high degree of religious tolerance that Prempeh demonstrated through his affirmation of traditional obligations while he attended Church and managed matters of the traditions of the Asante nation (Akyeampong, 1999).

The successful Asante northern military expeditions of the mid-18th century, which led to the incorporation of territories in the Volta Basin, also brought Asante into contact with Mande Muslim communities whose history of commercial travels to the fringes of the Akan forest dated back to the heydays of the TransSaharan trade. Consequently, Asante officials took advantage of Muslim services that included their knowledge in the making of prayers and Islamic talisman. Even today, a particular group of Muslims still visits the palace of the king and makes prayers regularly. All Asante rulers since 1903 see themselves as Anglicans, and, yet, see no conflict whatsoever in continuing the tradition of having Muslims and traditional priests of the Nsumankwaa perform prayers and rites at the palace (Akyeampong, Interviews with Nsumankwaahene aodl.org/islamictolerance/ asantehistory//object/3C-18C-B). In fact, the Asante kingdom at the height of its power in the early $19^{\text {th }}$ century either controlled or held influence over territories larger than the modern nation of Ghana. Thus, it can be argued that the manner, by which traditional authorities in the precolonial era related to Muslim merchants- 
Owusu-Ansah, D. \& Akyeampong, E/Religious Pluralism and Interfaith Coexistence: Ecumenicalism in the Context of Traditional Modes of Tolerance clerics, as well as to European traders and Christian missionaries, has contributed in a large measure to determining the politics of inter-religious relations in the country today.

\section{Taking Advantage of Religious Tolerance: Councils of Religious Bodies and the National Peace Council - Bringing the Past to Bear on the Present}

Similar to Archbishop Peter Akwasi Sarpong, whose interview was cited earlier, the foundational role of the indigenous religious culture in ensuring interfaith tolerance in Ghana was equally not lost on a leading Pentecostal pastor, Dr. Mensa Otabil of the International Central Gospel Church. In a 12 July 2006 interview, Dr. Otabil identified the indigenous religion culture as "the greatest buffer between Islam and Christianity" (See aodl.org/islamictolerance/asantehistory//objects/3C$18 \mathrm{C}-11 /)$. He expressed concern however that "as elements of the traditional religious culture thin out, [there could be] more confrontations between the world religions in this country." The observation was similar to that of Archbishop Sarpong, where the values of flexibility and accommodation were ascribed to the local culture rather than to the world religions.

In the same conversation, Dr. Otabil made two important observations. First, that conflict among religious groups often arises when fringe movements emerge to challenge the main faith. Second, that in an environment where the influence of the existing religions are more or less in a state of equilibrium, peaceful relations are best preserved and the destabilizing effects of fringe movements are best controlled if an umbrella forum under which disagreements are redressed exist. Thus, in 1984, a draft constitution for such a religious organization was written and promulgated for the creation of such an umbrella group in Ghana - the Forum of Religious Bodies.

Reverend Dr. Nathan Samwini, a former director of Christian-Muslim relations at the Ghana Christian Council, noted that the idea of creating the umbrella Forum of Religious Bodies emerged from conversations that dated back to 1978 . The primary concern then was how best to bring Muslim organizations in the country into dialogue with Christians (aodl.org/islamictolerance/seculareducation// object/47-1B7-4E/). The ability to construct such an organization was predicated on the fact that other religious councils existed in the country and had performed credibly well. The logical next step was the creation of a forum, at which members from the various religious organizations met from time to time for the purpose of redressing religious concerns amicably and articulating views on matters of national interest with a common voice. Member-organizations included in the religious forum were the Ahmadiyya Mission of Ghana, Federation of Muslim Councils of 
Ghana, Ghana Christian Council, Catholic Bishops Conference, and the Ghana Pentecostal Council. Prior to the formation of the Ghana Religious Forum, the most vocal and credible non-governmental religious groups that engaged governments on issue of social justice, and/or to redress conflicts resulting from partisan politics were the Christian Council of Ghana and the Conference of Catholic Bishops.

Equally critical to maintaining national peace are traditional chiefs whose political and cultural authority are rooted in the veneration of local ancestors and are legitimized by association with shrines. While the institution of chieftaincy and therefore chiefs is recognized politically as important players in redressing conflicts, the acknowledgement of priests of the indigenous shrines as representatives in national ecumenical peace-building organizations has been lacking until recently. We are here referencing the 2011 Parliamentary Act 818 that called for the establishment of National, Regional and District Peace Council Boards that were charged to "facilitate and develop mechanisms for conflict prevention, management, resolution and to build sustainable peace" in the country (Republic of Ghana, "National Peace Council Act, 2011 (Act) 818)," Accra, 2011). Gazetted on 20"th May 2011 and its members limited to four-year terms, the composition of the Peace Councils was intentionally inclusive. They comprise representations of the Catholic Bishops Conference, the Christian Council, National Council for Christian and Charismatic Churches, Ahmadiyya Muslim Mission, Ahl-Sunnah Muslim Group, Tijaniyya Muslim Group, Practitioners of African Traditional Religion, A member of the National House of Chiefs, two nominees of the Office of the President (one of whom must be a woman), and two persons who represent "identifiable" groups such as institutions of higher learning, civil society organizations involved in conflict resolution and peace building. The idea of establishing a group that considered the country's plurality of religious cultures is significant. An important advancement is the representation of a practitioner of the traditional religion and a representative of the Ghana Council of Chiefs - an implicit recognition of the legitimacy of Ghana's indigenous inclusive values.

\section{Concluding Remarks}

The activities of religious organizations are now an integral part of the history of the country. Similar to chieftaincy, institutions of Church and Mosque assume definite roles and articulate legitimate voices on issues relevant to national peace. These are the examples of the activities of local networks of organizations that TrustAfrica highlighted in its 2006/07 Annual Report. Researchers and scholars were called upon to stress the contributions of these local agencies to sustaining peace and reconciliation. The inclusion of practitioners of indigenous religions as 
members of the national agency that mediates peace and reconciliation in Ghana, even at the time when national census figures reported the majority of Ghanaians as identifying as members of the world religions, is a significant recognition that religious traditions that were hitherto described negatively as syncretic or viewed as backward by the educated, could be foundational to sustaining pluralistic values that are essential for inclusive democracy.

Indeed, it is essential for national governments to continue to recognize the importance of such networks of organizations. Equally important and insightful was Archbishop Sarpong's observation that the Christian missionaries who propagated the gospel in Ghana in the early decades of European rule missed an important opportunity to appreciate the inclusive pluralistic values of the traditional religion and culture that could have made it more successful in erecting the Church on a local foundation (Cosmas Ebo Sarbah, 2014). In fact, scholars and researchers should continue to explore, elaborate, and articulate the relevance of these religious traditions and experiences that underpin ecumenism and religious tolerance in Ghana. For, it is only under such peaceful conditions that the State, society, and the several religious communities can redress perceived discrimination relative to secular education and urban youth unemployment. 


\section{References}

Abamfo, O. A. (2013). Religion and the Inculturation of Human Rights in Ghana. Bloomsbury.

Akyeampong, E. (1999). Christianity, Modernity and the Weight of Tradition in the Life of 'Asantehene' Agyeman Prempeh I, c. 1888-1931. Africa: Journal of the International African Institute, 69 (2), 279-311.

Akyeampong, E. Interview with Baffour Domfe Gyeabuor III, Asantehene's Nsumankwaahene, aodl.org/islamictolerance/asantehistory//object/3C$18 \mathrm{C}-\mathrm{B} /$.

Akyeampong, Emmanuel and David Owusu-Ansah. (2008). List of Field Interviews at http://aodl.org/islamictolerance/asantehistory/.

Akyeampong, E. and Owusu-Ansah, D. (2014). Wealth in Knowledge: Spiritual Services and Political Power in Ghana. Paper presented for the African Studies Association Conference Panel on Mystical Agency as a Problem of Knowledge. Indianapolis, 22-23 November.

Amponsah, D. (2018). Kwame Nkrumah and the politics of religion in early postcolonial Ghana. Paper presented at the Ghana Studies Association panel Registers of Belief, Creativity and Power in Ghana at the African Studies Association annual conference in Atlanta, GA. 28 November-1 December.

Bob-Milliar, G. and Lauterback, K. (2018). A spiritual topography and history of Kwadaso, Kumasi. Paper presented as part the Ghana Studies Association panel Registers of Belief, Creativity and Power in Ghana, African Studies Association Conference, in Atlanta, GA. 28 November-1 December.

Diagne, S. B. (March 2009). Religion and the Public Space in Senegal: The Evolution of a Project of Modernity. Presented at the Institute for the Study of Islamic Thought in Africa (ISITA), Working Paper Series. Northwestern University, Evanston, IL.

Dumbe, Y. (2011). Islamic Revivalism in Contemporary Ghana. Sodertorn Studies on Religion, 5. Stockholm, Sweden.

Fisher, H. (1973). Conversion Reconsidered: Some Historical Aspects of religious Conversion in Black Africa. Africa: Journal of the International African Institute, 43 (1), 27-40.

Ghana Statistical Service. (2011). Population and Housing Census: Provisional Results, Accra, Ghana Statistical Service. 
Owusu-Ansah, D. \& Akyeampong, E/Religious Pluralism and Interfaith Coexistence: Ecumenicalism in the Context of Traditional Modes of Tolerance

Hagan, P. H. (1968). The Golden Stool and the Oath of the King of Ashanti. Research Review (University of Ghana), 4 (3), 1-33.

Hoexter, M., Eisenstadt, S. and Levtzion, N. (2002). The Public Sphere in Muslim Societies. State University of New York Press.

Horton, R. (1971). African Conversion. Africa, 41 (2), 85-108.

. (1975). On the Rationality of Conversion. Africa. 45, 373-399.

Horton, R. and Peel, J. A. (1976). Conversion and Confusion: A Rejoinder on Christianity in Eastern Nigeria. Canadian Journal of African Studies. 10, 481-498.

Iddrisu, A. (2013). Contesting Islam in Africa: Homegrown Wahhabism and Muslim Identity in Northern Ghana, 1920-2010. Carolina Academic Press.

Kobo, O. (2012). Unveiling Modernity in 20 ${ }^{\text {th }}$ Century West African Islamic Reforms. Brill.

Levtzion, N. (1968). Muslims and Chiefs in West Africa. Oxford.

Levtzion, N. (Ed.) (1979). Conversion to Islam. Holmes \& Meier.

Levtzion, N. and Fisher, H. (Eds). (1987). Rural and Urban Islam in West Africa. L. Rienner Publishers.

Masquelier, A. (1993). Narratives of power, images of wealth: the ritual economy of Bori in the market. In J. Comaroff and J. Comaroff (Eds.), Modernity and its Malcontents: ritual and power in postcolonial Africa. University of Chicago Press.

Meillassoux, C. (1993). Women in slavery in the Western Sudan. In J.M. Burns and E.K.

Ching (Eds.) Problems in African History: the precolonial centuries. New York, Markus Wiener.

Meyer, B. (2012). Christianity in Africa: From African Independent to PentecostalCharismatic Churches. In The Wiley Blackwell Companion to African Religions, (pp. 153-170). Wiley-Blackwell.

Owusu-Ansah, D. (1991). Islamic Talismanic Traditions in Nineteenth Century Asante. Edwin Mellen Press.

. (2015). 'Off to Northern Ghana in the Morning': Ramifications of a Trip, A review essay in honor of Ivor Wilks. Ghana Studies, 18, 177-182.

. (2005). Fieldnotes: Interview with Rev. Dr. Nathan Samwini (Ghana Christian 
Council Coordinator of Christian-Muslim Relations), dd. 18 July, Accra. See http:// aodl.org/islamictolerance/seculareducation//object/47-1B7-4E/.

Owusu-Ansah, D. and Akyeampong, E. (2008). Fieldnotes: Interviews at Antoa with Elders of the Antoa Shrine, dd. 12 July. Antoa, http://aodl.org/ islamictolerance/asantehistory/.

Owusu-Ansah, D., Iddrisu, A. and Sey, M. (2013). Islamic Learning, the State and the Challenges of Education in Ghana. Africa World Press.

Pew Research Center. (2010). Tolerance and Tension: Islam and Christianity in SubSaharan Africa. Pew Forum on Religion and Pubic Life, www.pewforum. org. April.

Sanneh, L. (1976). The Origins of Clericalism in West African Islam. Journal of African History, 17 (1), 49-72.

Sarbah, E. C. (2014). Notes from the Grassroots: Paradigm shift in theological formation towards interreligious dialogue in Ghana. Studies in Interreligious Dialogue, 24 (2), 225-236.

Sarpong, P. A. (1974). Ecumenical Relations in Ghana. Kampala: Uganda.

. (2002). People Differ: An Approach to Inculturation in Evangelisation. Accra: Sub-Saharan Press.

Stewart, C. (1999). Syncretism and its Synonyms: Reflections on Cultural Mixing. Diacritics, 29 (3), 40-62.

Weiss, H. (Ed.) (2002). Social Welfare in Muslim Societies in Africa. Nordiska Africkainstitutet.

Wilks, I. (1989). Asante in the Nineteenth Century: The Structure and Evolution of a Political Order. Cambridge University Press.

. (2011). Al-Hajj Salim Suware and the Suwarians: A Search for Sources. Transactions of the Historical Society of Ghana, 13, 1-80. 